\title{
Streptococcus cecorum, a New Species Isolated from Chickens
}

\author{
L. A. DEVRIESE, ${ }^{1 *}$ G. N. DUTTA, ${ }^{1}$ J. A. E. FARROW ${ }^{2}$ A. VAN DE KERCKHOVE ${ }^{1}$ AND B. A. \\ PHILLIPS $^{2}$
}

Faculty of Veterinary Medicine, Casinoplein 24, B-9000 Gent, Belgium, ${ }^{1}$ and National Institute for Research in Dairying, Shinfield, Reading RG2 9AT, England ${ }^{2}$

\begin{abstract}
Carboxyphilic strains which had characteristics commonly attributed to the group D streptococci and especially to Streptococcus bovis were isolated from the ceca of chickens. However, these strains differed from $S$. bovis in being positive for ribose, melezitose, $\beta$-glucuronidase, and alkaline phosphatase, and negative for group $\mathrm{D}$ reactions and growth enhancement by $\mathrm{CO}_{2}$. These differences were confirmed by deoxyribonucleic acid-deoxyribonucleic acid hybridization tests. The strains form a new species, for which the name Streptococcus cecorum is proposed. Strain A60 ( = NCDO 2674) is the type strain of this species.
\end{abstract}

During an investigation of the susceptibilities of intestinal bacteria isolated from chickens to antimicrobial agents used in farm animals (G. N. Dutta, D. Vet. Sci. thesis, University of Gent, Gent, Belgium, 1983), a group of carboxyphilic streptococci was found which could not be identified as any known streptococcal species. The strains in this group were able to grow at $45^{\circ} \mathrm{C}$ and in the presence of $40 \%$ bile, two characteristics which are commonly attributed only to the enterococci or group D streptococci. After the tests advocated by Facklam (6) and Sharpe (21) for the separation of fecal streptococci from other streptococci (growth at $\mathrm{pH} 9.6$, in $6.5 \%$ $\mathrm{NaCl}$, and at 10 and $45^{\circ} \mathrm{C}$ ) were performed, the strains were tentatively identified as Streptococcus bovis. However, three reactions were in discordance with this identification; the strains failed to react with the Streptococcus group D antisera used, they were able to grow to a limited extent at $\mathrm{pH} 9.6$, and their growth was definitely better in an atmosphere containing $5 \%$ $\mathrm{CO}_{2}$ than in air.

A subsequent biochemical and genetic study showed that these strains should be designated a new species, which is described here.

\section{MATERIALS AND METHODS}

Strains. Strains A2a, A16, A29, A37 through A40, and $A 60^{\mathrm{T}}(\mathrm{T}=$ type strain) were isolated from the ceca of eight chickens from eight farms in Belgium by using Islam medium (12) supplemented with $30 \mu \mathrm{g}$ of neomycin per $\mathrm{ml}$ and $15 \mu \mathrm{g}$ of nalidixic acid per $\mathrm{ml}$. The plates were incubated for $48 \mathrm{~h}$ in $5 \% \mathrm{CO}_{2}$ in air. $S$. bovis CCM 5616 was obtained from the Czechoslovak Collection of Microorganisms, Brno. Other reference strains were obtained from the National Collection of Dairy Organisms (NCDO), Shinfield, Reading, England.
Media and culture incubation. Media were obtained from Oxoid Ltd., Basingstoke, England, unless otherwise stated. Cultures were normally incubated at $37^{\circ} \mathrm{C}$.

Growth characteristics. Growth on sheep bloodColumbia agar plates was compared after incubation aerobically and in a $5 \% \mathrm{CO}_{2}$ atmosphere for 16 and 48 h. All of the other tests except the API tests were performed in a 5 to $10 \% \mathrm{CO}_{2}$ atmosphere.

Biochemical reactions. Dextran and levan formation was tested on heart infusion agar supplemented with $5 \%(\mathrm{wt} / \mathrm{vol})$ sucrose. Acid production was tested in phenol red broth base (GIBCO, Paisley, Scotland) containing $1 \%(\mathrm{wt} / \mathrm{vol})$ carbohydrate. Glycerol fermentation was tested anaerobically on the solidified medium described above. Reactions were read after 24 and $72 \mathrm{~h}$. Other tests were performed by using API 20 Strep and API 50CH galleries according to the instructions of the manufacturer (API, Basingstoke, England). The galleries were a gift from API. Digestion of starch was tested on Mueller-Hinton agar (Difco Laboratories, Detroit, Mich.).

Physiological test. The hemolysis test and the CAMP reaction test (4) were performed on sheep bloodColumbia agar. Catalase activity was tested with $3 \%$ $\mathrm{H}_{2} \mathrm{O}_{2}$. Reduction of potassium tellurite was tested by using Tellur tablets (Rosco, Taastrup, Denmark). Hippurate hydrolysis $(5,11)$, reactions in $0.1 \%$ methylene blue-milk $(5,24)$, ammonia production from arginine (17), reduction of triphenyl tetrazolium chloride (6) production of L-tyrosine decarboxylase (20), hyaluronidase, and chondroitin sulfatase (25), pyruvate hydrolysis (10), and gelatinase production (15) were tested by methods described previously.

Resistance tests. Tests for growth at pH 9.6, in 6.5\% $\mathrm{NaCl}$, and at 10 and $45^{\circ} \mathrm{C}$ were performed in duplicate in Todd-Hewitt broth (GIBCO) and in medium A of Barnes et al. (2), and the results were recorded after 24 and $72 \mathrm{~h}$. Survival at $60^{\circ} \mathrm{C}$ for $30 \mathrm{~min}$ was tested by using fully grown cultures in capillary pipettes and inocula diluted $1: 100$ in tubes containing the prewarmed media described above. Growth on $40 \%$ bile was tested on bile-esculin agar, and growth inhibition was tested on Slanetz-Bartley medium, kanamy- 
cin-esculin-azide agar, Edwards medium, and mitissalivarius agar (GIBCO). Resistance to $2.75 \% \mathrm{KSCN}$ was tested on brain heart infusion agar as described by Skorkovsky (23). Minimum inhibitory concentrations (MIC) of antibiotics were determined by using the agar dilution method and Mueller-Hinton agar (26).

Pathogenicity test. Chickens which were 3 months old were injected intravenously with $1 \mathrm{ml}$ of an overnight Todd-Hewitt broth culture containing approximately $5 \times 10^{8}$ colony-forming units of strain A16, observed for 3 weeks, and then euthanized and necropsied.

Chemotaxonomic studies. Cultures were grown for deoxyribonucleic acid (DNA) preparation, isolation of DNA, determinations of base compositions, and DNA-DNA hybridizations as previously described (6a). For fatty acid analyses, dry cells were degraded by acid methanolysis (16), and fatty acid methyl esters were examined by gas-liquid chromatography as described by Farrow et al. (6a).

Serology. The strains were tested against commercially available antisera.

\section{RESULTS AND DISCUSSION}

Biochemical and physiological reactions. The results of the tests which differentiated the cecal isolates from other streptococci isolated from poultry and $S$. bovis are given in Table 1 . Other carboxyphilic species of streptococci (e.g., Streptococcus anginosus, Streptococcus constellatus, Streptococcus intermedius, Streptococcus mitis, and Streptococcus morbillorum) are raffinose and inulin negative; Streptococcus sanguis is arginine positive, and Streptococcus mutans and "Streptococcus milleri" do not grow at $45^{\circ} \mathrm{C}(13,18,22)$. The $\mathrm{CO}_{2}$-dependent strains from bovine mastitis described by Schwan et al. (19) differ from the cecal isolates by exhibiting negative reactions for inulin, melezitose, raffinose, and ribose. Streptococcus gallinarum (3) differs from the cecal isolates in its biochemical reactions (Table 1), in exhibiting a group D serological reaction, and in possessing menaquinones and a different fatty acid profile (Farrow et al., in press). Similarly, S. bovis may be distinguished from the cecal isolates by its negative ribose, melezitose, $\beta$-glucuronidase, and alkaline phosphatase reactions, although this species is poorly defined (8). Streptococcus uberis differs in bile resistance, in growth at $45^{\circ} \mathrm{C}$, in producing $\mathrm{NH}_{3}$ from arginine, and in fermenting mannitol and sorbitol but not raffinose (7). Therefore, the cecal isolates are easily distinguished from all of the species of streptococci described above.

Inhibition tests. The results of the MIC tests are shown in Table 2, and these results partially differentiate the cecal strains from $S$. bovis. In addition, the cecal isolates do not grow in $2.75 \%$ $\mathrm{KSCN}$, in $0.4 \% \mathrm{~K}_{2} \mathrm{Te}_{2} \mathrm{O}_{3}$, on Slanetz medium, or on kanamycin-esculin-azide agar. Small colo- nies appeared on Edwards medium after 2 days, and well-developed slimy light blue colonies formed on mitis-salivarius agar.

Pathogenicity test. The cecal strains were nonpathogenic in the infection model which we used.

DNA base composition. The DNAs base of the cecal isolates contained 37 to $38 \mathrm{~mol} \%$ guanine plus cytosine $(\mathrm{G}+\mathrm{C})$; these values are similar to values reported previously for Streptococcus faecalis (9), Streptococcus faecium (9), S. mutans (9), and $S$. bovis (9). Under the same conditions, Leuconostoc mesenteroides NCDO 768 DNA had a $\mathrm{G}+\mathrm{C}$ content of $39 \mathrm{~mol} \%$, and Escherichia coli K-12 NCDO 1984 DNA had a $\mathrm{G}+\mathrm{C}$ content of 51 to $52 \mathrm{~mol} \%$.

DNA-DNA hybridization. The specific activity of ${ }^{3} \mathrm{H}$-labeled DNA from strain $\mathrm{A} 60^{\mathrm{T}}$ was approximately $3,300 \mathrm{cpm} / \mu \mathrm{g}$. The cecal isolates formed a single homology group that was 82 to $102 \%$ related to strain $A 60^{\mathrm{T}}$. None of the four species having similar DNA base compositions was related to strain $A 60^{\mathrm{T}}$. The homology values for $S$. bovis strains NCDO $597^{\mathrm{T}}$, NCDO 599 , NCDO 2019, NCDO 2571, and NCDO 2594 were $29,31,35,22$, and $28 \%$ respectively; the homology values for $S$. faecalis NCDO $581^{\mathrm{T}}, S$. faecium NCDO $942^{\mathrm{T}}$, and $S$. mutans NCDO $2062^{\mathrm{T}}$ were 21,16 , and $19 \%$, respectively. Streptococcus sp. strain NCDO 2137, which resembles $S$. bovis biochemically (Farrow, unpublished data) was $24 \%$ related to strain $A 60^{\mathrm{T}}$. All the results given above were obtained by using optimum hybridization conditions (melting temperature minus $25^{\circ} \mathrm{C}$ ).

Fatty acid analyses. The 3 cecal isolates examined possessed predominantly straight-chain saturated and monounsaturated fatty acids (Table 3). The major fatty acids corresponded to hexadecanoic $\left(\mathrm{C}_{16: 0}\right)$ and octadecenoic $\left(\mathrm{C}_{18: 1}\right)$ acids. Cyclopropane ring acids were either absent or present in only trace amounts (Table 3 ). It is worth noting that $S$. bovis and related strains also possess major amounts of $\mathrm{C}_{16: 0}$ and $\mathrm{C}_{18: 1}$ acids and generally lack cyclopropane ring acids (J. A. E. Farrow, A. J. Bramley, J. Kruze, B. A. Phillips, and M. D. Collins, manuscript in preparation). However, the absence of lactobacillic acid $\left(\mathrm{C}_{19} \Delta\right)$ in the cecal isolates clearly distinguishes them from $S$. faecalis and $S$. faecium, which possess substantial levels (10 to $15 \%$ ) of this acid (Farrow et al., in press).

The data given above indicate that the cecal isolates belong to a new species of the genus Streptococcus. Both the DNA-DNA hybridization data and the fatty acid profiles suggest a closer relationship to $S$. bovis than to the enterococci or oral streptococci. DNA-ribosomal ribonucleic acid hybridization of these strains with representatives from these groups $(9,14)$ may 
TABLE 1. Characteristics that differentiate $S$. cecorum from $S$. bovis and other streptococci isolated from poultry ${ }^{a}$

\begin{tabular}{|c|c|c|c|c|c|c|c|}
\hline Characteristic & $\begin{array}{c}S . \text { cecorum } \\
\text { (cecal isolates) }\end{array}$ & S. bovis & "S. avium" & S. faecalis & S. faecium & $\begin{array}{l}\text { S. galli- } \\
\text { narum }\end{array}$ & $\begin{array}{l}\text { S. pleo- } \\
\text { morphus }\end{array}$ \\
\hline Growth in the presence of $\mathrm{O}_{2}$ & $+^{b}$ & + & + & + & + & + & - \\
\hline Growth at $10^{\circ} \mathrm{C}$ & - & - & + or $-c$ & + & + & + & - \\
\hline Growth at $\mathrm{pH} 9.6$ & w & \pm or $-c$ & + & + & + & + & \\
\hline Survival at $60^{\circ} \mathrm{C}$ for $30 \mathrm{~min}$ & - & - & + & + & + & $\mathrm{D}$ & \\
\hline Growth in $6.5 \% \mathrm{NaCl}$ & - & - & + or $w^{c}$ & + & + & + & \\
\hline Arginine hydrolysis & - & - & \pm or $-c$ & + & + & - & \\
\hline Hippurate hydrolysis & - & - & - & + & \pm & + & \\
\hline Pyrrolidonylarylaminidase & - & - & + & + & + & + & \\
\hline$\alpha$-Galactosidase & $\pm^{e}$ & + & - & - & - & + & \\
\hline$\beta$-Glucuronidase & + & - & - & - & - & + & \\
\hline$\beta$-Galactosidase & $\pm^{e}$ & - & - & - & + & + & \\
\hline Alkaline phosphatase & + & - & - & - & - & - & \\
\hline Group D antigen & - & + & + & + & + & + & \\
\hline \multicolumn{8}{|l|}{ Acid from: } \\
\hline Glycerol & - & - & \pm & + & \pm or $-c$ & \pm & \\
\hline L-Arabinose & - & - & \pm & - & + & + & \\
\hline Ribose & + & - & + & + & + & + & \\
\hline D-Xylose & - & - & - & + & + & + & \\
\hline Adonitol & - & - & + & - & - & - & \\
\hline Galactose & + & + & + & + & + & + & + \\
\hline Sorbose & - & - & + & - & - & - & \\
\hline Rhamnose & - & - & \pm & \pm & \pm & - & \\
\hline Mannitol & - & \pm & + & + & + or $\pm c$ & + & \\
\hline Sorbitol & - & - & + & + & - & - & \\
\hline$\alpha$-Methyl-D-mannoside & - & - & \pm & - & \pm & - & \\
\hline$\alpha$-Methyl-D-glucoside & - & - & + & - & \pm & + & \\
\hline Salicin & + & + & + & + & + & + & - \\
\hline Cellobiose & + & + & + & + & + & + & - \\
\hline Maltose & + & + & + & + & + & + & - \\
\hline Lactose & + & + & + & + & + & + & - \\
\hline Melibiose & + & + & + or $\pm^{c}$ & - & \pm or $+^{c}$ & + & \\
\hline Sucrose & + & + & \pm & \pm & + & + & - \\
\hline Inulin & + & \pm & - & - & \pm & \pm & \\
\hline Melezitose & + & - & + & + & - & - & \\
\hline D-Raffinose & + & + & - & - & \pm & + & \\
\hline Starch & $\pm^{d}$ & + & - & - & - & - & \\
\hline Glycogen & $\pm^{d}$ & \pm & - & - & - & - & \\
\hline Xylitol & - & - & \pm & - & - & - & \\
\hline D-Turanose & - & - & - & - & \pm & + & \\
\hline D-Lyxose & - & - & + & - & - & - & \\
\hline D-Tagatose & $\pm(\mathrm{w})^{d}$ & - & + & + & \pm & + & \\
\hline D-Arabitol & - & - & + & - & - & - & \\
\hline L-Arabitol & - & - & \pm & - & - & - & \\
\hline Gluconate & - & - & \pm & + & \pm & + & \\
\hline 2-Ketogluconate & $\pm(w)^{e}$ & - & + & - & - & - & \\
\hline 5-Ketogluconate & $\pm(\mathrm{w})^{e}$ & - & - & - & - & - & \\
\hline
\end{tabular}

${ }^{a}$ Data from references $1,3,6,13$, and 21 and unpublished data.

$b+, \geqslant 90 \%$ positive;,$- \leqslant 10 \%$ positive;,$\pm>10<90 \%$ positive; $w$, usually weak reactions. These percentages may not be reliable in the case of $S$. cecorum and " $S$. avium' because they are based on results obtained with a small number of strains.

${ }^{c}$ Conflicting data have appeared in the literature.

${ }^{d}$ Type strain NCDO 2674 is positive.

$e^{e}$ Type strain NCDO 2674 is negative.

establish the exact taxonomic status of the new species within the genus Streptococcus as currently defined. The new species is formally proposed below.

Streptococcus cecorum sp. nov. (ce.co'rum. L. n. cecum sacculated diverticulum of the large intestine [cecum]; N.L. gen pl. n. cecorum of ceca) cells are gram-positive cocci 1 to $1.3 \mu \mathrm{m}$ in diameter and occur in pairs, short chains, or small groups. Within the chains and groups the cells are arranged in pairs. The cells are nonmotile and nonsporing. Colonies are circular with 
TABLE 2. MICs of selective substances and antibacterial agents for $S$. cecorum and $S$. bovis

\begin{tabular}{lcr}
\hline \multirow{1}{*}{ Substance } & \multicolumn{2}{c}{ MIC range $(\mu \mathrm{g} / \mathrm{ml})$} \\
\cline { 2 - 3 } & S. cecorum & $\begin{array}{c}\text { S. bovis } \\
\text { CCM } 5614\end{array}$ \\
\hline K-Tellurite & $250-500$ & 500 \\
Tetrazolium & $250-500$ & 500 \\
Sodium azide & $500-2000$ & 4,000 \\
Crystal violet & $1-2$ & 4 \\
Acriflavine & 4 & 1 \\
Thallium acetate & $1,024->2,048$ & 1,024 \\
Penicillin G & $<0.12-2$ & \\
Tetracycline & $1-64^{a}$ & \\
$\quad$ hydrochloride & $0.5->128^{a}$ & \\
Erythromycin & $<0.12->128^{a}$ & \\
Lincomycin & $>256$ & \\
Sulfamethoxazole & $<1->128^{a}$ & \\
Monensin & $<0.12-32^{a}$ & \\
Bacitracin & $0.25-2$ & \\
Carbadox & $1-2$ & \\
Avoparcin & $<0.25-0.25$ & \\
Flavomycine &
\end{tabular}

${ }^{a}$ Some strains have acquired resistance.

entire edges, low convex, partially translucent, and not pigmented and reach 1 to $2 \mathrm{~mm}$ in diameter after $20 \mathrm{~h}$ and 2 to $3 \mathrm{~mm}$ after 2 days at $37^{\circ} \mathrm{C}$ in $\mathrm{CO}_{2}$ in air. Growth is slower and less abundant in air. The strains show good growth anaerobically in an $\mathrm{H}_{2}-\mathrm{CO}_{2}$ atmosphere. Uniform turbidity with a small deposit is formed in brain heart infusion broth and Todd-Hewitt broth. Fermentative metablism. Gas is not formed from glucose. Good growth occurs at $45^{\circ} \mathrm{C}$, but no growth occurs at $10^{\circ} \mathrm{C}$, in $6.5 \%$ $\mathrm{NaCl}$, in $2.75 \% \mathrm{KSCN}$, in $0.4 \% \mathrm{~K}_{2} \mathrm{Te}_{2} \mathrm{O}_{3}$, on Slanetz medium, or on kanamycin-esculin-azide agar. Growth at $\mathrm{pH} 9.6$ is slower and less abundant than growth at $\mathrm{pH}$ 7.0. Slight inhibition by $40 \%$ bile. Strains do not survive $60^{\circ} \mathrm{C}$ for 30 min. Hemolytic on sheep blood agar, producing greening. Strains are negative in the CAMP reaction test, in tests for ammonia from arginine, pyrrolidonylarylaminidase, and gelatinase, tyrosinase, and in conventional and API hippurate tests. The majority of the strains react in rapid hippurate tests (only strain A16 is negative). Tetrazolium is not reduced. Dextran and levan are not formed. Hydrolysis of starch is variable; two strains (strains A6 and A28) are amylase positive in the Mueller-Hinton starch digestion test, but only strain A37 does not react in the API-amidon test. Esculin is hydrolyzed. Alkaline phosphatase, leucine arylaminidase, $\beta$-glucuronidase, and Voges-Proskauer positive. $\alpha$ and $\beta$-galactosidase tests are variable; only strains A16 and A39 are positive in these tests. Most strains produce hyaluronidase and chondroitin sulfatase (only strain A16 is negative in these two tests). Variable and not easily repro-
TABLE 3. Fatty acid composition of $S$. cecorum

\begin{tabular}{ccccccc}
\hline \multirow{2}{*}{ Strain } & \multicolumn{5}{c}{ Fatty acid composition (\%) } \\
\cline { 2 - 7 } & $\mathrm{C}_{14: 0}$ & $\mathrm{C}_{16: 0}$ & $\mathrm{C}_{16: 1}$ & $\mathrm{C}_{18: 0}$ & $\mathrm{C}_{18: 1}$ & $\mathrm{C}_{19 \Delta}$ \\
\hline NCDO 2669 & 2.0 & 35.0 & 4.5 & 13.5 & 45.0 & \\
NCDO 2671 & 2.5 & 38.5 & 3.5 & 14.5 & 41.0 & \\
NCDO 2674 $^{\mathrm{T}}$ & 2.0 & 27.5 & 3.5 & 9.5 & 47.0 & 0.5 \\
\hline
\end{tabular}

ducible reactions occur in methylene blue-milk. Acid is formed from $\mathrm{N}$-acetylglucosamine, amygdalin, arbutin, cellobiose, fructose, galactose, glucose, $\beta$-gentiobiose, inulin, lactose, maltose, mannose, melezitose, melibiose, raffinose, ribose, salicin, sucrose, and trehalose. Variable reactions with glycogen (strains A29 and $\mathrm{A} 60^{\mathrm{T}}$ react positively). Some weak reactions occur with tagatose, 2-ketogluconate, and 5ketogluconate. Acid is not formed from adonitol, D- or L-arabinose, D- or L-arabitol, dulcitol, erythritol, fucose, $\alpha$-methyl-D-glucoside, glycer$o l$, inositol, lyxose, mannitol, $\alpha$-methyl-D-mannoside, L-rhamnose, sorbitol, L-sorbose, turanose, xylitol, xylose, or $\beta$-methyl-xyloside. The DNA base composition ranges from 37 to $38 \pm 1$ $\mathrm{mol} \% \mathrm{G}+\mathrm{C}$. The long-chain fatty acids are straight-chain saturated and monounsaturated acids. The major fatty acids are hexadecanoic and octadecenoic $(\omega 7)$ acids. Lactobacillic acid is either absent or is present in only trace amounts.

The eight strains of $S$. cecorum have been deposited in the National Collection of Dairy Organisms as strains NCDO 2667 through 2674. The type strain is strain NCDO $2674(=\mathrm{A} 60)$. The reactions of strain NCDO $2674^{\mathrm{T}}$ are those of the majority of the strains, but this strain has acquired tetracycline (MIC, $16 \mu \mathrm{g} / \mathrm{ml}$ ), erythromycin (MIC, $>128 \mu \mathrm{g} / \mathrm{ml}$ ), lincomycin (MIC, $>128 \mu \mathrm{g} / \mathrm{ml}$ ), and bacitracin (MIC, $4 \mu \mathrm{g} / \mathrm{ml}$ ) resistances. The DNA base composition of strain NCDO $2674^{\mathrm{T}}$ is $37 \mathrm{~mol} \% \mathrm{G}+\mathrm{C}$.

\section{ACKNOWLEDGMENTS}

We are grateful to M. D. Collins, National Institute for Research in Dairying, for assistance in determining fatty acid profiles.

\section{LITERATURE CITED}

1. Barnes, E. M., C. S. Impey, B. J. H. Stevens, and J. L. Peel. 1977. Streptococcus pleomorphus sp. nov.: an anaerobic streptococcus isolated mainly from the caeca of birds. J. Gen. Microbiol. 102:45-53.

2. Barnes, E. M., M. Ingram, and G. C. Ingram. 1956. The distribution and significance of different species of faecal streptococci in bacon factories. J. Appl. Bacteriol. 19:204-211.

3. Bridge, P. D., and P. H. A. Sneath. 1982. Streptococcus gallinarum sp. nov. and Streptococcus oralis sp. nov. Int. J. Syst. Bacteriol. 32:410-415. 
4. Christie, R., N. E. Atkins, and E. Munch-Petersen. 1944. A note on a lytic phenomenon shown by group B streptococci. Aust. J. Exp. Biol. Med. Sci. 22:197-200.

5. Cowan, S. T. 1965. Manual for the identification of medical bacteria. Cambridge University Press, London.

6. Facklam, R. R. 1972. Recognition of group D streptococci species of human origin by biochemical and physiological tests. Appl. Microbiol. 23:1131-1139.

6a.Farrow, J. A. E., D. Jones, B. A. Philips, and M. D. Collins. 1983. Taxonomic studies on some group D streptococci. J. Gen. Microbiol. 129:1423-1432.

7. Garvie, E. I., and A. J. Bramley. 1979. Streptococcus uberis -an approach to its classification. J. Appl. Bacteriol. 46:395-404.

8. Garvie, E. I., and A. J. Bramley. 1979. Streptococcus bovis-an approach to its classification and its importance as a cause of bovine mastitis. J. Appl. Bacteriol. 46:557566.

9. Garvie, E. I., and J. A. E. Farrow. 1981. Sub-divisions within the genus Streptococcus using deoxyribonucleic acid/ribosomal ribonucleic acid hybridization. Zentralbl. Bakteriol. Parasitenkd. Infektionskr. Hyg. Abt. 1 Orig. Reihe C 2:151-165.

10. Gross, K. C., M. P. Houghton, and L. B. Senterfit. 1975. Presumptive speciation of Streptococcus bovis and other group D streptococci from human sources by using arginine and pyruvate tests. J. Clin. Microbiol. 1:54-60.

11. Hwang, M., and G. M. Ederer. 1975. Rapid hippurate hydrolysis method for presumptive identification of group B streptococci. J. Clin. Microbiol. 1:114-115.

12. Islam, A. K. M. S. 1977 . Rapid recognition of group B streptococci. Lancet i:256-257.

13. Jones, D. 1978. Composition and identification of the genus Streptococcus, p. 1-49. In F. H. Skinner and L. B. Quesnel (ed.), Streptococci. Academic Press, Inc., London.

14. Kilpper-Balz, R., G. Fischer, and K. H. Schleifer. 1982. Nucleic acid hybridization of group $\mathrm{N}$ and group $\mathrm{D}$ streptococci. Curr. Microbiol. 7:245-250.

15. King, E. O. 1959. Studies on a group of previously unclassified bacteria associated with meningitis in infants. Am. J. Clin. Pathol. 31:241-247.
16. Minnikin, D. E., L. Alshamaony, and M. Goodfellow. 1975. Differentiation of Mycobacterium, Nocardia and related taxa by thin-layer chromatographic analysis of whole-organism methanolysates. J. Gen. Microbiol. 88:200-204.

17. Niven, C. F., K. L. Smiley, and J. M. Sherman. 1942. The hydrolysis of arginine by streptococci. J. Bacteriol. 43:651-660.

18. Pulliam, L., R. K. Porschen, and W. K. Hadley. 1980 Biochemical properties of $\mathrm{CO}_{2}$-dependent streptococci. J. Clin. Microbiol. 12:27-31.

19. Schwan, O., C. E. Nord, and O. Holmberg. 1979. Biochemical characterization of unidentified microaerophilic cocci isolated from heifer and dry-cow mastitis. J. Clin. Microbiol. 10:622-627.

20. Sharpe, M. E. 1948. Some biochemical characteristics of group D streptococci isolated from infant faeces, with special reference to their tyrosine decarboxylase activity. Proc. Soc. Appl. Bacteriol., p. 13-17.

21. Sharpe, M. E. 1979 . Identification of lactic acid bacteria p. 233-259. In F. A. Skinner and D. W. Lovelock (ed.) Identification methods for microbiologists. Academic Press, Inc., London.

22. Sisson, P. R., H. R. Ingham, and J. B. Selkon. 1978. A study of carbon dioxide-dependent strains of Streptococcus milleri. J. Med. Microbiol. 11:111-116.

23. Skorkovsky, B. 1973. Eine Modifikation des Rhodanidtests zur Differenzierung von Enterokokken-RM-test. Zentralbl. Bakteriol. Parasitenkd. Infektionskr. Hyg. Abt. 1 Orig. Reihe A 224:71-76.

24. Smith, D. G., and P. M. F. Shattock. 1964. The cellular location of antigens in streptococci of the group D, N and Q. J. Gen. Microbiol. 34:165-175.

25. Smith, R. F., and N. P. Willett. 1968. Rapid plate method for screening hyaluronidase- and chondroitin sulfataseproducing microorganisms. Appl. Microbiol. 16:14341436.

26. Washington, J. A., II, and A. L. Barry. 1974. Dilution test procedures p. 410-417. In E. H. Lennette, E. H. Spaulding, and J. P. Truant (ed.), Manual of clinical microbiology, 2nd ed. American Society for Microbiology, Washington, D.C. 